\title{
La colección pictórica de D. Lorenzo Armengual de la Mota, peculiar ejemplo del interés por la pintura y la miniatura en la primera mitad del siglo XVIII
}

\author{
Sebastián GonzÁlez Segarra *
}

\begin{abstract}
RESUMEN
ABSTRACT

La importancia de las colecciones pictóricas en España, durante el siglo XVIII, parece ser puesta cada vez en más clara evidencia conforme se avanza en la investigación de

los protocolos notariales. De entre las muchas documentadas hasta ahora, la que fue propiedad del malagueño, consejero de

Castilla y Obispo de Cádiz, D. Lorenzo Armengual de la Mota, es digna de ser reseñada y analizada por su riqueza en número de obras, autoría y valor económico. La presencia que las miniaturas tienen en ella es de considerable importancia. Es uno de los ejemplos más tempranos de la afición desarrollada en la península hacia este tipo de obras, que alcanzará un especial desarrollo a partir de la segunda mitad del siglo, que necesita, sin duda, un más atento y

The importance of pictorial collections in Spain during the eighteenth century becomes increasingly obvious as research on notarial protocols becomes more advanced. From the collections researched so far, one, the property of the Malaguenian councillor of Castile and Bishop of Cádiz, D. Lorenzo Armengual de la Mota, is worth mentioning and analysing because of its range, size, and economic value. The presence that miniatures have within it is also of considerable importance as it represents one of the earliest examples of a trend that would be more fully developed in the Iberian Peninsula in the second half of the century without doubt, a more detailed study is required.
\end{abstract} pormenorizado estudio.

En España, los prelados, en algunos casos, desarrollaron un importante papel en relación con la pintura a través de la promoción de las fábricas de sus palacios, de las obras mayores y menores del obispado o de otros lugares

* Tercer Ciclo. Departamento de Historia del Arte. UNED. 
de culto, de donaciones 0 , incluso, por medio de su interés por el coleccionismo, ya que, normalmente, se veían obligados a mantener un tren de vida fastuoso, contando con un gran palacio, residencias secundarias, caballerizas, servidumbre..., si bien la fastuosidad era mucho menor cuando se trataba de prelados de origen regular ${ }^{1}$, porque, posiblemente, se encontraban más identificados con unos planteamientos que tienden a considerar axiomático que cuanto sobrase al obispo de su decente ostentación y cumplimiento de los deberes anejos a su cargo debería de ser destinado a los pobres ${ }^{2}$.

Pero estos últimos planteamientos podían ser diversamente interpretados, de manera que, a pesar del freno que suponía el expolio ${ }^{3}$, podemos encontrarnos con prelados que muestran un claro interés por acumular un importante patrimonio pictórico, interés que también podía existir entre el clero, especialmente entre la alta jerarquía relacionada con el cabildo catedralicio.

Ejemplos de este gusto por la pintura podemos encontrar en algunos prelados relacionados con la ciudad de Málaga: Fray Alonso de Santo Tomás ${ }^{4}$, Fray Francisco de San José ${ }^{5}$, Fray Manuel de Santo Tomás ${ }^{6}$, el

\footnotetext{
Mestre Sanchís, Antonio. "La iglesia en la España de los siglos XVII y XVIII», en García VILlosladA, Ricardo (dir.). Historia de la Iglesia en España, Madrid, 1979, pág. 33.

2 Ibídem, págs. 230-231.

3 Se entiende por tal al conjunto de bienes que quedan por muerte de los prelados o religiosos. Éstos, que antiguamente correspondian a las iglesias de sus respectivos beneficiados, fueron, posteriormente, reservados a la Santa Sede. En España fueron parciales, por ser costumbre muy antigua el que los beneficiados dispusieran de los bienes profecticios por acto de última voluntad.

4 En los años de su episcopado desarrollan su actividad artística los más importantes escultores y pintores de la localidad, Niño de Guevara y Mena, con los que tenía, al igual que con Alonso Cano, amistosas relaciones, no debiendo de ser ajeno a la promoción artística, pues, como hombre barroco, culto y de importantes dotes intelectuales, supo comprender y aprovechar las posibilidades que la cultura brindaba para hacer llegar sus ideas al pueblo, con una mayor facilidad y eficacia. Morales Folguera, José Miguel. «Las ideas estéticas de Fray Alonso de Santo Tomás», en VV.AA. Fray Alonso de Santo Tomás y la Hacienda del Retiro, Málaga, 1994, pág. 201.

Díaz Escobar habla de la existencia de un colección privada del obispo en la Hacienda del Retiro, entre cuyas obras se podian encontrar algunas de Niño de Guevara, extremo del que no se ha llegado a tener constancia documental, ya que el inventario de las obras allí existentes corres. ponde a sus compradores, los Condes de Buenavista SAURET GUERRERO, Teresa. «Fray Alonso de Santo Tomás y su promoción de las artes plásticas", ibídem, pág. 286.

${ }_{5}$ Según la «Memoria de bienes que se heredaron por muerte de Fray Francisco de San José", realizada el día 2 de febrero de 1713 , se relacionan, como heredadas por la catedral: un lienzo de vara y media del Descendimiento de la cruz, con moldura negra; un lienzo de vara de largo de Nuestro Señor Captivo sin moldura; un lienzo de vara de San Francisco, sin moldura; un lienzo de una imagen de Nuestra Señora, con moldura dorada; un lienzo de vara de San Francisco sin moldura; un lienzo de una imagen de Nuestra Señora con moldura dorada y un frontal de pintura. A.C.C.MA. Legajo 558, fol. 1

6 Con ocasión de su fallecimiento, se entregaron a la fábrica de la Catedral, el 19 de diciembre de 1717, diversos bienes de pontifical, entre los que se encontraban los siguientes cuadros, apreciados por Diego de la Cerda: un lienzo de Nuestra Señora de Belén y San José con su marco, afreciado en 200 reales; un lienzo de San Jerónimo con marco negro valorado en 100
} 
Arzobispo de Zaragoza, D. Antonio Ybáñez de la Riba Herrera y el obispo de Cádiz D. Lorenzo Armengual de la Mota.

A pesar de todo, el interés por la pintura de obispos y alta jerarquía eclesiástica, en Málaga, durante los años que corresponden al reinado de Felipe $V$, no debió ser excesivamente importante. La información que nos ofrecen algunos documentos, relativos a sus expolios o bienes de pontifical, muestra, en todos los casos, conjuntos numéricamente humildes, entre los que no encontramos referencias a autores ni escuelas concretas, por lo que se ha de pensar que debía de tratarse de obras fundamentalmente dovocionales, que formarían parte de los patrimonios episcopales más por este valor que por el puramente artístico. El hecho de que todas las obras citadas en estas fuentes, con excepción del retrato de Carlos II, sean de temática religiosa, así como el valor que las obras correspondientes al pontifical de Fray Manuel de Santo Tomás tenían (la más cara fue valorada en 200 reales), pueden confirmar esta apreciación.

Dos casos especiales, y estrechamente vinculados entre sí, vienen representados por las figuras de D. Antonio Ybáñez de la Riba Herrera, natural de Cantabria y magistral en la ciudad, que llegó a ser Arzobispo de Zaragoza y Virrey de Aragón, y D. Lorenzo Armengual de la Mota, natural del popular, pesquero y malacitano barrio del Perchel, que llegó a ser Arzobispo de Cádiz, uno de los cuatro ministros del Gabinete Real y presidente del Consejo de Hacienda.

El primero, que abordó la dotación de la Capilla del Pilar en la Catedral de Málaga ${ }^{7}$, antes de ser promovido al obispado de Ceuta, fue durante va-

reales; un lienzo de la Magdalena sin marco, otro de San Antonio de Padua y otro del Salvador, todos en el mismo precio que el cuadro anterior; y cinco láminas de papel valoradas en cinco reales. A estas obras se unió un lienzo de la Huida de Egipto, con su moldura, valorado en 180 reales, que junto a las prendas de los pontificalas y otros bienes fueron vendidos para pagar los costos. A.C.C.MA. Legajo 14, vol. 34.

Además de éstos hay que citar los bienes que recibe $D$. José de Espejo, de mano de $D$. Bernardino de Cuéllar, para ser entregados al Sr. Marqués de Olías, procedentes del expolio del Sr. Obispo. Entre ellos se encontraban los siguientes cuadros: uno grande con el retrato de Carlos II y su dosel y coronación carmesí, con su cenefa a franjas, un cuadro de San Francisco Javier, con su marco y doce cuadros grandes con los doce Apóstoles, con sus marcos. A.H.P.MA. Escribanía de Antonio Ramos Plaza, legajo 2247, año 1714, fols. 242-246.

${ }^{7}$ En esta capilla se hizo un retablo dorado, en el que se colocó la imagen de la Virgen del Pilar, posiblemente a la devoción de D. Antonio, según se puede conjeturar del texto que acompaña a su retrato, existente en la catedral. Dotó un aniversario para dicha capilla, que se cumplía el 12 de octubre, y otro a Santa Teresa. Imágenes de esta Santa, junto a San José, y de San Antonio Abad y San Antonio de Padua, se encuentran en los altares colaterales, siendo obras, al parecer, de Diego de la Cerda. Todo el adorno de la capilla fue costeado por él y mandó, igualmente, en el año 1708, varias reliquias. MEDINA CONDE, Cristóbal. Descripción de la Santa Iglesia Catedral de Málaga desde el 1487 de si erección hasta el de 1785, Málaga, 1878, págs. $156-157$. 
rios años Magistral de la Catedral de Málaga. En este cargo, por su competencia teológica y conocimientos, se ganó la confianza de Fray Alonso de Santo Tomás ${ }^{8}$ y trabó amistad con Pedro de Mena ${ }^{9}$ y con D. Juan de Pedregal, racionero de la misma catedral, que según podemos deducir de su colección ${ }^{10}$ era, sin duda, aficionado y conocedor de la pintura. Su carrera política y eclesiástica llegó hasta los más altos cargos: presidente del Consejo de Castilla ${ }^{11}$, virrey de Aragón, arzobispo de Zaragoza y arzobispo de Toledo ${ }^{12}$.

Su afición por la pintura no sólo queda certificada por sus iniciativas de decoración pictórica de la capilla del Pilar, en la catedral malacitana, sino también por las tomadas como Arzobispo de Zaragoza. En ésta ciudad trabajó para él Pablo Rabiella y Díez de Aux, quien realiza, por encargo suyo, el lienzo de "Santiago en la batalla de Clavijo", de la capilla de la Seo, mandada construir por él, en el año 1695. Donó, igualmente, para el Palacio Episcopal de esa ciudad, con fecha 8 de abril de 1693, 77 cuadros de los que 48 correspondían a obispos de medio cuerpo, y el resto, a diversos asuntos religiosos. Según Arturo Ansón estos retratos debieron de ser encargados por el arzobispo a Pablo Rabiella y realizados con intervención del taller ${ }^{13}$.

8 Romero Torres, José Luis. «El artista, el cliente y la obra de arte», en Pedro de Mena 1628-1688, exposición Catedral de Málaga, Abril, 1989, Sevilla, 1989, págs. 97-114.

- Bajo su tutela realizó los estudios eclesiásticos el hijo menor del escultor, José de Mena, y su firma se puede encontrar en las cartas de profesión de sus hijas, existentes en el Convento del Císter, del cual fue protector. CAMACHO, Rosario. Las cartas de profesión de las hijas de Pedro de mena. Conmemoración del III centenario de la muerte del escultor, Real Academia de Bellas Artes de San Telmo, Málaga, 1988, págs. 4-7.

10 Este racionero, era el capitular que llegó a poseer una más extensa colección de pintura, ya que, según el inventario realizado con ocasión de la partición de sus bienes, protocolizada el 19 de diciembre de 1721, poseía 95 cuadros valorados en 4497 reales. Destacan, entre ellos, ocho cobres de la Historia de David, valorados en 1440 reales. Precisamente, en su colección llama la atención la destacada presencia de láminas de cobre, 27, y el alto valor del conjunto de este tipo de obras, que aicanza los 2569 reales, más de la mitad del valor de toda la colección. A.H.P.MA. Escribanía de Francisco León y Castillo, legajo 2376, año 1721, fols. 90-91.

Una interesante colección de consultas correspondientes al disfrute de este cargo, de procedencia desconocida (posiblemente del fondo de la Cía. de Jesús) se encuentra en la Biblioteca Universitaria de Granada (manuscrito A-60). GAN GIMÉNEZ, Pedro. "Las "consultas" del Presidente Ibáñez (1690-1692)», Miscelánea de estudios dedicados al profesor Antonio Marín Ocete, tomo I, Granada, 1974, págs. 295-322.

12 Blasco IJAZO, José. Obispos que han regido la diócesis de Zaragoza, Zaragoza, 1959, págs. 43-44.

13 ANSON, Arturo. "Colección de retratos de los obispos y arzobispos de Zaragoza hasta el siglo XVIII inclusive». En VV.AA. El espejo de nuestra historia. La diócesis de Zaragoza a través de los siglos, Zaragoza, 1991, pág. 145. 
Colaborador del anterior ${ }^{14}$, hasta el punto de recibir el poder para otorgar su testamento ${ }^{15}$, fue $\mathrm{D}$. Lorenzo Armengual de la Mota. La relación entre ambos debió contribuir decisivamente a desarrollar su gusto e interés por la pintura y la protección hacia las actividades artísticas, facilitada por los importantes puestos que va alcanzando a nivel eclesiástico y político: prebendado en la Catedral de Santiago, visitador general, vicario y obispo auxiliar en Zaragoza, obispo de Cádiz ${ }^{16}$, entre 1717 y 1730, año de su fallecimiento, ministro del Gabinete Real, presidente de Hacienda ${ }^{17}$, capellán y vicario general de la Real Armada del mar Océano ${ }^{18}$.

En el caso de D. Lorenzo Armengual encontramos, además de su concreta actuación como mecenas y promotor artístico en su diócesis ${ }^{19}$, un interés especial por salvaguardar su patrimonio personal dentro de la familia,

14 Siendo D. Antonio Ybañez magistral, al pasear cerca del puerto, se cuenta que conoció a un muchacho, un hijo de humildes pescadores nacido en el barrio del Perchel, el mes de noviembre de 1663, que tiraba con todas sus fuerzas de un copo cargado de peces. Admirado de su arrogante hombría, entabló con él una conversación que sería el inicio de una gran amistad. No habiendo podido estudiar, por tener que ayudar a la familia en sus tareas pesqueras, la protección del magistral hizo posible que ocupara un puesto de Colegial en el Estudio de Gramática, abierto en la claustra de la antigua Catedral, iniciando así sus estudios eclesiásticos. Con el tiempo, al ser nombrado D. Antonio arzobispo de Zaragoza, estuvo siempre a su lado, llegando a ser su albacea testamentario.

${ }_{15}$ Este poder fue otorgado el 2 de septiembre de 1710. ZARAGOZA, Fray Lamberto de. Teatro Histórico de las iglesias del Reino de Aragón, tomo IV, Pamplona, 1725, pág. 153.

${ }_{16}$ A este puesto accede, precisamente, al dejar la administración, como solía ser frecuente entre los eclesiásticos que llegaron a ocupar cargos en los Consejos. FAyARD, Janine. Los miembros del Consejo de Castilla (1621-1746), Madrid, 1982, pág. 129.

17 La presidencia de este Consejo era a la que, normalmente, tenían más fácil acceso los consejeros, mientras que las de otros se encontraban, por lo general, copadas por la nobleza. Ibídem, pág. 129.

18 GonzÁlez, Vidal. «Lorenzo Armengual de la Mota (1663-1730)», en AlCoBendas, Miguel (edición y prólogo). Málaga, personajes en su historia, Málaga, 1986, págs. 181-183.

La leyenda de la humildad de su origen puede ser puesto un tanto en duda por el nombramiento de Lorenzo Armengual, hijo de Lorenzo Armengual y Theresa del Pino, al cargo de Capellán de Honor de S.M. el 27 de mayo de 1690, tras la realización de su expediente de limpieza de sangre. A.G.P., caja 7812, expediente 4.

Su nombramiento, como obispo de Cádiz, lo relaciona, Pablo Antón Solé, con los relevos de gobiernos tras la paz de Utrech y la llegada de Isabel de Farnesio. AnTón Solé, Pablo. La iglesia gaditana en el siglo XVIII, Cádiz, 1994, págs. 152-163.

Su labor en Cádiz estuvo caracterizada por su interés promotor de obras artísticas, caritativas y catequéticas, como muestran la promoción del Hospital de Mujeres o las informaciones derivadas de su visita pastoral. A.D.CA. Visita pastoral de D. Lorenzo Armengual de la Mota, 1717-1718.

19 Durante los años de su episcopado se reinició la obra de la Catedral de Cádiz y, a su costa, entre 1722 y 1726, se levantó, bajo la dirección de Juan López de Algarín, la iglesia de San Lorenzo. Su exterior, igual que numerosos edificios gaditanos de la época, se decoraba, en su paramento, con una decoración polícroma, que perfilaba los sillares en ocre rojizo y enmarcaba los vanos con molduras mixtilíneas de color amarillo, mientras la portada iba en rojo. SIERRA FERNÁNDEZ, Lorenzo y Juan Alonso de la. "Juan López de Algarín, Maestro Mayor de la lglesia del señor S. Lorenzo de Cádiz», Gades, nº 13, Cádiz, 1985, págs. 267-271. 
lo cual determina que, en vida, realice una importante donación «inter vivos", de obras de arte, a su hermana $D^{\underline{a}}$ Jacinta Armengual de la Mota, marquesa de Campo Alegre ${ }^{20}$, esposa que fue de D. Alonso Verdugo.

Esta donación se realiza en Cádiz, mediante escritura pública otorgada el 20 de junio de $1719^{21}$, haciéndose una pormenorizada relación de todos los objetos que la integran, entre lo cuales, junto a una rica biblioteca, se incluye una importante colección de pinturas y, lo que es más inusual, de miniaturas.

Sin duda, como indica Morales y Marín, el estudio de la miniatura y de los miniaturistas en España, durante el siglo XVII y XVIII, es una importante laguna en la bibliografía española ${ }^{22}$. Este arte tuvo su origen en la decoración con minio (de la costumbre de subrayar o colorear las iniciales de los manuscritos con color rojo) de los manuscritos medievales, momento en el que se precisa su técnica, siguiendo los pasos de la pintura al temple ${ }^{23}$. Tras el grave eclipse que supuso, para esta técnica, la aparición de la imprenta resurge, desligada ya del libro, en el siglo XVII y alcanza su plenitud de desarrollo en el XVIII, solicitada por una sociedad de gustos refinados, amante de lo bello y exquisito, adquiriendo precios cada vez más altos. Su difusión se vio favorecida por la costumbre de la Corte de regalar pequeños objetos ornamentados con las efigies de los reyes a los embajadores extranjeros, cuando eran removidos de sus cargos, o intercambiarlos entre las familias reales al prometerse los esposos. En el siglo XVII estas obras suelen realizarse al óleo y sobre soporte de metal, con medidas normalmente inferiores a los $10 \mathrm{cms}$. El incremento de su éxito, durante el siglo XVIII, parece estar relacionado con el comienzo de la utilización del marfil en láminas muy finas, sobre las que se pintaba a la aguada, consiguiendo una atractiva transparencia en las tonalidades de la piel y una gran delicadeza en los matices de los adornos. Esta técnica fue utilizada, en primer lugar, por

Se utilizaba un procedimiento decorativo semejante al que, podíamos encontrar en varias edificaciones malagueñas de la época. "Cuando Málaga no era blanca. La arquitectura pintada del siglo XVIII», Boletín de Arte, no 13-14, Málaga, 1993, págs. 143-170.

En su interior destacan el retablo mayor, obra de Francisco López, iniciada en el año 1727, la policromada imagen de San Lorenzo, realizada por Miguel Taramas en 1725, y, en dos retablos laterales, dos grandes lienzos traídos de Roma por el obispo Armengual, en los que se representan a San Liborio y San Rafael. SierRA FernánDEz, Juan Lorenzo. Cádiz. Guía artística y monumental, Cádiz, 1995, págs. 138-140.

20 Este título fue concedido, a $D^{a}$ Jacinta, por Felipe $V$, el 6 de mayo de 1716, por los servicios prestados por su hermano. GonZález, Fernando. Diccionario Heráldico y Nobiliario de los reinos de España, Madrid, 1987, pág. 97.

2) A.H.P.CA. Escribanía de Nicolás de Alburquerque, legajo 5318, año 1719, fols. 620-718.

22 Morales y Marín, José Luis. Pintura en España 1750-1808, Madrid, 1994, pág. 285.

23 Maltese, Corrado (coord.). Las técnicas artísticas, Madrid, 1990, pág. 306. 
el miniaturista inglés Bernard Lens, pero su principal impulso se debió a la obra de la veneciana Rosalba Carriera, establecida en París en 1720. Tanto utilizando la técnica al pastel, como la aguada, la moda se propagó rápidamente por toda Europa, realizándose medallones y otros objetos con una ejecución minuciosa, destacando en España, la familia Meléndez ${ }^{24}$. El interés por ella parece fortalecerse, especialmente, durante la primera mitad del siglo $\mathrm{XVIII}$, como demuestra la generalización del uso de los retratos miniatura como regalo diplomático, en los que se especializa Francisco Antonio Meléndez, tras su llegada de Italia, desde el año 1719, llegando a obtener el cargo de pintor miniaturista ${ }^{25}$. Este éxito se prolonga en los años siguientes, con la dedicación a esta actividad, de pintores como Carlos Casanova ${ }^{26}$.

La relación de obras es la que sigue:

- Un puerto de Nápoles de tres varas de largo y siete cuartas de ancho en 600 reales.

- Cuatro marinas de vara y media de largo y una vara de ancho en 280 reales.

- Seis países marinas de la misma medida con marcos negros y perfil dorado en 540 reales.

- Otra marina de íres varas de largo y vara y media de alto con marco negro y perfil dorado en 240 reales.

- Otra marina del puerto de Gibraltar de siete cuartas de ancho y vara y cuarta de alto con marco negro y perfil dorado en 80 reales.

- Un país nevado de vara y media de ancho marco negro y perfil dorado en 80 reales.

- Cuatro marinas de dos varas y media de largo y vara y media de alto con el mismo marco en 1200 reales.

- Dos marinas de dos varas de largo por una vara y tres cuartos con los mismos marcos en 600 reales.

- Un cuadro de Santa Teresa de una vara en cuadro con marco negro

24 JUNQUERA, Paulina. «Miniaturas retratos en el Palacio de Oriente», Reales Sitios, I trimestre 1971, Madrid, n² 27, págs. 86-89.

25 Espinosa, María del Carmen. «El retrato miniatura de los regalos diplomáticos españoles del siglo XVIII", en Actas del Congreso El arte en las Cortes Europeas del siglo XVIII, Madrid, 1989, págs. 264-268 y TOMÁS, Marino. La miniatura retrato en España, Madrid, 1953, págs. 16-35.

26 ANSÓn NAVARRO, Carlos. “Notas sobre Carlos Casanova, pintor de Cámara y grabador aragonés", en Actas del Congreso El arte en las Cortes Europeas del siglo XVIII, Madrid, 1989, págs. $51-61$. 
y dorado en 50 reales.

- Un cuadro de San Francisco original de Dominico Greco de dos varas y media de alto y vara y media de ancho con marco de talla dorada en 900 reales ${ }^{27}$.

- Dos pinturas ochavadas de dos fábulas originales del Caballero Farelli con marco dorado en 960 reales.

- Un cuadro de una Virgen con Niño y dos ángeles de tres cuartas de alto y dos tercia de ancho con marco fingido de charol y tarjetas doradas en 330 reales.

- Un cuadro de Santa Teresa y Nuestra Señora poniéndole un collar y unos ángeles de siete cuartas de alto y vara y tercia de ancho en 100 reales.

- Un país sobreventana de dos varas de largo y media vara de ancho con marco negro en 33 reales.

- Dos países de una vara de alto y dos tercias de ancho con marco negro y dorado en 80 reales.

- Dos países sobreventanas de siete cuartas de ancho y una tercia de alto con marco negro y perfiles dorados en 60 reales.

- Un Santo Obispo Mártir San Agustín de siete cuartas de alto y vara y tercia de ancho con marco de talla dorada en 330 reales.

- Una marina de tres varas de largo y vara y media de ancho con marco negro y arquitrabe dorado en 500 reales.

- Cuatro marinas de una vara y media por vara y cuarta con marcos negros y perfil dorado en 1000 reales.

- Dos marinas de vara y media por tres cuartas de alto con marco negro y perfil dorado en 360 reales.

- Otras dos marinas de iguales dimensiones y marco en 200 reales.

- Una marina pequeña de dos tercias de ancho y media vara de alto con marco negro y perfil dorado en 100 reales.

- Una imagen de Nuestra Señora y San José con un San Juan y un cordero original de Alonso Cano de dos tercia de alto por media vara de ancho con marco de ébano y perfil dorado en 1500 reales.

${ }^{27}$ Esta obra debe ser el que actualmente se encuentra en el antiguo Hospital de Mujeres de Cádiz. PEMAN, Cesar. El arte en Cádiz, Madrid, 1930, s/n. 
- Una lámina de San Francisco Javier de media vara de alto y algo menos de ancho con marco de ébano y moldura dorada en 500 reales.

- Dos marinas pequeñas con marco dorado 300 reales.

- Un paisito pequeño de una tercia por una cuarta con marco negro y perfil dorado 60 reales.

- Dos marinas pequeñas de tabla de la misma medida y marco en 132 reales.

- Dos pinturas, una de San Pablo y otra de Santa Cecilia de tres cuartas por media vara con marco dorado en 240 reales.

- Una lámina de piedra de San José con el Niño de una cuarta en cuadro con marco negro y perfil dorado en 66 reales.

- Una lámina de piedra del Samaritano de una tercia por una cuarta con el mismo marco en 150 reales.

- Seis láminas pequeñas una de la Trinidad, otra de una Magdalena, otra del Angel de la Guarda, otra de San Miguel, otra de San Juan Bautista y una Descanso de Nuestra Señora con marco negro y dorado 270 reales.

- Una marina de siete cuartas de largo por una de alto con marco negro de ébano, marfil y bronce en 660 reales.

- Un retrato de D. Antonio Ybáñez de la Riba de una vara de alto por tres cuartas de ancho con marco negro y dorado 220 reales.

- Un retrato de Fray Alonso de Santo Tomás de la misma medida y marco en 120 reales.

- Dos láminas copias de Rubens la una del Nacimiento y la otra de la Adoración de los Reyes de vara y cuarta de largo y una vara de alto con marco de ébano en 1200 reales.

- Una pintura de San Juan de Dios escuela de Cano de siete cuartas de alto y vara y tercia de ancho con marco negro y perfil dorado en 330 reales.

- Una imagen de San Francisco Javier de una vara de alto por tres cuartas de ancho y perfil dorado en 70 reales.

- Una pintura de Nuestra Señora del Pópulo de media vara de alto y una tercia de ancho con marco negro y perfil dorado en 40 reales.

- Una pintura de San José y el Niño de una tercia en cuadro con marcos negros y perfil dorado 45 reales.

- Seis fruteros de siete cuartas por cinco cuartas 198 reales. 
- Una imagen de la Trinidad y Santo Tomas de Villanueva de vara y media por vara con marco negro y perfil dorado 180 reales.

- Una pintura de Nuestra Señora de los Desamparados de Valencia de vara y media por vara y tercia con marco negro en 100 reales.

- Un retrato de Felipe $V$ de la misma medida y marco en 150 reales.

- Una imagen de San Jerónimo en tabla de tres cuartas por dos tercias en 180 reales.

- Una pintura de Nuestra Señora contemplando al niño dormido de una tercia en cuadro con marco dorado en el mismo precio .

- Una pintura ovalada en lámina de Nuestra Señora, el Niño y San Juan con piedras y bronces en 120 reales.

- Una pintura en piedra de San Antonio con marco de ébano bronceado de hechura ochavada en 66 reales.

- Una lámina de Nuestra Señora de la Encarnación de una sexma con marco de ébano y perfil dorado en 50 reales.

- Una pintura en piedra de San Pedro cuando le saca el ángel de la prisión una sexma de ancho marco plateado y adorno de bronce en 120 reales.

- Otra pintura San Juan de seis dedos de alto con marco de ébano y bronce en 60 reales.

- Dos pinturas, una de San Francisco en lámina y otra de San Francisco de Borja en tabla con marcos de palosanto y concha en 120 reales.

- Una pintura de Santiago de una cuarta en cuadro con marco dorado en 90 reales.

- Una pintura de Nuestra Señora con San Juan y San Francisco con vidrio christal delante de más de una tercia de alto con marco de palosanto bronceado en 100 reales.

- Una pintura en piedra de Santa María y San José ovalada con marco bronceado de una sexma en 60 reales.

- Un lienzo de Nuestra Señora de la Encarnación marco de concha de una sexma en cuadro ochavada en 50 reales.

- Una pintura en piedra del martirio de San Pedro con marco de ébano y friso de jaspe con sus toques bronceados en 80 reales.

- Una vitela de Santa Teresa con marco de concha y molduras ondeadas en 15 reales. 
- Cuatro vitelas en miniatura de una sexma de alto de diferentes figuras con sus vidrios y marco de palosanto en 160 reales.

- Un retrato de un religioso mercedario de una vara de alto por vara y tercia de ancho en 20 reales.

- Otra pintura de Nuestra Señora del Pópulo con marco de ébano y vidrio de cristal delante en 18 reales.

- Dos láminas, una de la Soledad y otra del Nazareno en relicario con engarce de plata en 80 reales.

- Una imagen de Nuestra Señora con la Ánimas de más de una vara de alto por tres cuartas de ancho con marco negro en 30 reales.

- Una pintura de Nuestra Señora y el Niño con el mundo en la mano de tres cuartas en cuadro por 30 reales.

- Una pintura de tres cuartas de alto por media vara de ancho con marco dorado bodegón con hígado de cordero y diferentes piezas de él en 80 reales.

- Un biombo de ocho hojas pintado al temple de dos varas y cuarta de alto maltratado en 150 reales.

- Una biombo de siete hojas y tres cuartas de ancho cada una y dos varas y media de alto pintura de Flandes imitado a tema de flores en 800 reales.

- Una historia del Martirio de San Lorenzo en marfil de una cuarta de alto con marco de latón y acero tallado de altorrelieve en 1000 reales ${ }^{28}$.

- Un San Sebastián en marfil con su martirio en altorrelieve de una cuarta de alto con marco de latón y acero en 400 reales.

- Una pintura de Nuestra Señora contemplando al niño dormido de una vara y media por vara y cuarta de ancho marco negro y arquitrabe dorado en 300 reales.

- Dos pinturas en vidrio de la Magdalena y San Juan de tres cuartas de ancho por media vara de alto con marcos tallados y dorados en 600 reales.

- Una pintura de Nuestra Señora y el Niño de vara y cuarta de alto por una vara de ancho con marco negro en 300 reales.

- Una pintura de San Antonio de Padua de la misma medida y marco en 500 reales.

\footnotetext{
28 A partir de esta obra, todas se citan, en el inventario realizado en Madrid (ver nota 31), ubicados en el gabinete.
} 
- Tres retratos de los pontífices Inocencio XI, Alejandro y Clemente XI de tres cuartas de alto y dos tercias de ancho con marco negro y perfil dorado en 360 reales.

- Un retrato de San Francisco de Sales de las mismas características en 120 reales.

- Una pintura, tabla de una marina con San Pedro apóstol predicando desde una nave, de vara y tercia de ancho y tres cuartas de alto con marco tallado y dorado en 300 reales.

- Seis láminas, cuatro de las partes del año, otra de la Visitación de Nuestra Señora de tres cuartas de ancho por media vara de alto con marco negro y perfil dorado en 1800 reales.

- Dos pinturas, una de San Rafael y Tobias y la otra de San Pedro Armengol de Antonio Palomino en unos paisitos de media vara de ancho y una tercia de alto con marco dorado en 800 reales.

- Cuatro marinas del mismo tamaño y marco con diferentes figuras y navichuelos en 720 reales.

- Una pintura de San Francisco de la misma mano de las marinas, tamaño y marco en 240 reales.

- Dos pinturas, una de la Trinidad de la Tierra y otra del Descanso de Nuestra Señora de media vara de ancho y una tercia de alto con marcos negros y perfil dorado en 200 reales.

- Dos cabezas de muchachos, una de un canónigo y otra de cabeza de hombre, las de los muchachos de mano de Murillo ${ }^{29}$, la del canónigo de mano de Cano y el hombre de Carreño de media vara de alto y una tercia de ancho con marcos dorados en 720 reales.

- Dos cabezas más pequeñas, una mujer de manos de Juan Carreño y otra de autor no conocido de una cuarta de alto y poco más o menos de ancho con marcos dorados en 100 y 50 reales.

- Dos láminas de San Sebastián y Santa Bárbara de la misma medida con marco negro y perfil dorado 100 reales.

29 Angulo, en el catálogo razonado de obras de Murillo, cita estas dos obras y el documento del Archivo Diocesano de Cádiz, pero las identifica como dos muchachos. Las incluye en el grupo de obras discutibles, erróneamente atribuidas o con información insuficiente, con el $n^{\circ} 2.453$ y 2.453 .

En el mismo apartado del catálogo se citan algunas obras de dimensiones semejantes. Una en la colección de Lord Cowley, que no pudo localizar (reg. 2498) y otra en la colección Massel de 37,5*30 $\mathrm{cm}$.(reg. 2513), dimensiones éstas cercanas a las que señala para las obras de Armengual (42*28 cm.). Angulo IÑIgueZ, Diego. Murillo, catálogo crítico, vol. Il, Madrid, 1981, págs. 537 y 540. 
- Dos láminas de San Ignacio y San Pedro del mismo tamaño y marco en 120 reales.

- Dos países de El Bosco redondos con el marco cuadrado y dorado una del Incendio de Sodoma y otra una Marina con peñas en 132 reales.

- Una tabla ovalada del Infierno, de El Bosco de cerca de una cuarta más o menos con cuadro en marco cuadrado en 120 reales.

- Un país en lámina del mismo tamaño en 66 reales.

- Dos pinturas del mismo tamaño, Cristo sacando a Santos Padres del seno de Abraham y otra de tres figurillas y una cabra en 120 reales.

- Dos países con unas cacerías de mas de tres cuartas de ancho y media vara de alto con marcos dorados en 160 reales.

- Dos pinturas la una de una cotorra o papagayo y la otra de un mono de media vara de alto y una tercia de ancho con marco dorado en 110 reales.

- Cuatro países en tabla de media vara en cuadro con marco dorado en 400 reales.

- Ocho pinturas países y marinas, tres láminas y cinco tablas, uno Historia del Samaritano en 300 reales de una tercia por una cuarta con marco negro y perfil dorado con una tarjetilla en los ángulos de hoja de plata, y los siete a 120 reales, en 1140 reales.

- Dos pinturas de unos bamboches de media vara de ancho por una tercia de alto con diferentes figuras y ganados con marcos dorados a 360 reales cada una en 720 reales.

- Dos pinturas de ovejas y cabrillas de una cuarta en cuadro con marco dorado en 140 reales.

- Una pintura en lámina de un riachuelo con marco negro redondo y perfil dorado en 500 reales.

- Dos países redondos ${ }^{30}$ en tabla de una tercia de diámetro con marco torneado y dorado en 700 reales.

30 La utilización de formatos circulares parece hacerse frecuente, especialmente entre los paisajistas flamencos, desde el siglo XVI, quizás por su transportabilidad, por las posibilidades que ofrecían para las formas decrecientes, siendo considerados especialmente aptos para series como las de los cuatro elementos o los cinco sentidos. Además esta forma podía asociarse a la idea del paso del tiempo y de la Rueda de la Fortuna. Sutron, Peter C. El siglo de Oro del Paisaje Holandés. Catálogo de la Exposición, Fundación Thyssen-Bornenisza, Madrid, 1995, pág. 114. 
- Dos pinturas de dos niños un Cupido y un Atlante de media vara de alto y una tercia de ancho en 160 reales.

- Un país en vidrio de Pedro Cotto en medio punto con marco dorado de una tercia de alto en 300 reales.

- Diez países en tabla de una cuarta de ancho y poco menos de alto con marco dorado en 500 reales.

- Seis países en tabla de la misma mano algo más pequeños en 270 reales.

- Seis paises algo más pequeños y del mismo género en 240 reales.

- Seis países del mismo género más pequeños, cuatro de la misma mano y dos distintos en 216 reales.

- Dos países de tres cuartas de largo y dos tercias de alto con marco dorado en 400 reales.

- Cinco países de dos tercias de ancho y media vara de alto con marcos dorados en 450 reales.

- Cuatro países redondos flamencos en tabla de una cuarta en diámetro con marcos dorados y torneados en 400 reales.

- Dos pinturas de pájaros muertos de dos tercias de ancho y media vara de alto con marcos dorados en 360 reales.

- Una copia de Rubens de San Lorenzo en el martirio de una tercia de alto y una cuarta de ancho con marco negro y perfil dorado en 240 reales.

- Una pintura Adoración de los Reyes de una tercia de alto por una cuarta de ancho con marco negro y dorado en 100 reales.

- Dos láminas, una de la Virgen con el Niño copia de Gerardo Segre y Ecce Homo copia de Jacobo Palma de una tercia de alto y una cuarta de ancho con marco tallado y dorado en 360 reales.

- Dos láminas de San Agustín y Santa Catalina de Siena con marcos negro y perfil dorado en 160 reales.

- Dos láminas de San Marcos y San Lucas de una sexma de alto y algo menos de ancho con marcos negro y perfil dorado en 120 reales.

- Otra pintura de miniatura de Nuestra Señora y el Niño de una tercia de alto y una cuarta de ancho con vidrio cristal y marco tallado y bronceado en 900 reales.

- Dos floreros de mano de Juan de Arellano de media vara de alto y una tercia de ancho con marcos dorados en 150 reales. 
- Una lámina de José de Castro de una cuarta en cuadro con marco negro y perfil dorado en 66 reales.

- Una lámina ovalada Nuestra Señora con el Niño un cristal delante de menos de una cuarta de alto con marco negro y perfil dorado y sobrepuestos o cantoneras de plata en 90 reales.

- Una lámina de la Virgen con el Niño, San José y la Magdalena de casi el mismo tamaño y marco negro y perfil dorado en 55 reales.

- Una lámina de San Jerónimo de sexma con marco negro y perfil dorado en 30 reales.

- Una lámina de Nuestra Señora y Cristo muerto en el regazo de una cuarta más o menos de alto y menos de una cuarta de ancho con perfil dorado en 36 reales.

- Seis países de pluma de casi una cuarta de ancho y media vara de alto con vidrio y marco de palosanto en 360 reales.

- Dos países marinas del mismo tamaño en lienzo al óleo en 600 reales.

- Cuatro láminas de tabla con diferentes figuras de vacas, pastores y cabañas y otros de mas de una tercia en cuadros y marcos dorados en 600 reales.

- Una Nuestra Señora con un Cristo en el regazo, copia de Aníbal Carraci de cerca de media vara más o menos y una tercia con marcos de cristal y bronce dorado y cantoneras talladas en 240 reales.

- Una pintura en vidrio azogado con marco de bronce redondo de Nuestra Señora y el Niño en 100 reales.

- Un cuadro de Nuestra Señora de los Siete Dolores pequeña con marco cristal bronceado en 100 reales.

- Una lámina de la Asunción copia de Rubens de una vara más o menos de alto y tres cuartas de ancho en 700 reales.

- Una pintura en tabla del Descendimiento de la Cruz de Cristo de menos de una cuarta por media cuarta con marco de ébano en 700 reales, de mano de Alberto.

Junto a estas pinturas se relacionan las siguientes «pinturas de miniaturas guarnecidas de acero":

- Dos países en vitela de un cuarto de sexma con marco de acero tallado y adornos pavonados en 600 reales. 
- Otras dos en vitela con dos países, uno de Cristo y San Juan en el desierto con unos ángeles que bajan una cruz y la otra más pequeña de una fuente $y$ diferentes ruinas en 600 reales.

- Dos vitelas, una sin colorir de Cristo coronando a Santa Teresa y la otra de dos figuras coloridas las diosas Zeres y Juno de una cuarta en cuadro con marco de bronce dorado en 1.100 reales.

- Dos países, una mujer vestida de un manto azul y dos muchachos junto a la margen de un arroyo de una sexma por una octava otro de una figura a caballo hablando a un pobre y otras figurillas y ganados junto a unas casserias con marco de bronce y cobollos de acero pabonado y en medios mascarones blancos en 900 reales.

- Dos floreros de vitela de un ochavo de alto y un poco menos de ancho con marco de bronce dorado tapas y copete de acero pabonado blanco en 600 reales.

- Un país con cinco figuras a orillas de un río con marco de bronce dorado tapas y copete de acero pabonado blanco en 700 reales.

- Una imagen de Nuestra Señora en un colgante de flores con marco de bronce dorado tapas y copete de acero pabonado blanco en 400 reales.

- Una vitela de Diana de caza con marco de bronce dorado tapas y copete de acero pabonado blanco en 350 reales.

- Un país con San Francisco de una cuarta con marco de bronce dorado tapas y copete de acero pabonado blanco en 450 reales.

- Una vitela de San José orlado de flores de una cuarta con marco de bronce dorado tapas y copete de acero pabonado blanco en 900 reales.

- Una imagen de Nuestra Señora con el Niño en lámina de una sexma de alto por un ochavo de ancho con marco de bronce dorado tapas y copete de acero pabonado blanco en 300 reales.

- Una imagen de Nuestra Señora en vitela con marco de acero redondo más o menos del tamaño de un real de a ocho en 180 reales.

- Un retrato al olio de seis dedos de alto por cuatro de ancho con marco de bronce dorado tapas y copete de acero pabonado blanco en 450 reales.

- Una Lucrecia de cinco dedos en cuadro con marco de bronce dorado tapas y copete de acero pabonado blanco en 250 reales.

- Dos miniaturas en hueso de José en la cárcel y José sacándole de la cesterna de seis dedos de alto con marco de bronce dorado tapas y copete de acero pabonado blanco en 480 reales. 
- Tres miniaturas de hueso en ovalo de José el Casto, José cuando dejo la capa a la mujer de Putifar y José vendido a los gitanos con marco de bronce dorado tapas y copete de acero pabonado blanco en 750 reales.

- Una miniatura de hueso un viejo tomando tabaco y un vaso de vino en una mano de siete dedos de alto con marco de bronce dorado tapas y copete de acero pabonado blanco en 200 reales.

- Un retrato Madona sobre hueso de cuatro dedos ovalado con marco de bronce, acero y adornos blancos en 180 reales.

- Tres miniaturas de hueso, dos Juguetes de niños, la otra hombre y mujer y una mona que le está sacando el dinero de una bolsa de seis dedos de ancho con marco de bronce, acero y adornos blancos en 720 reales.

- Otras dos del mismo material ovaladas de Juno y Venus ambas en unos carros con marcos de bronce, acero y adornos blancos en 600 reales.

- Otras dos de hueso ovalado de hombre al fuego tomando tabaco y dos figuras lamentándose de haberse vertido la jarra de vino con marco de bronce, acero y adornos blancos en 300 reales.

- Otras dos de hueso de hombre con una tabaquera y otra con un papel de solfa como cantando con marco de bronce, acero y adornos blancos en 400 reales.

- Otras dos de hueso ovaladas una de un hombre apuntando a una figura que tiene en la mano y la otra un hombre comiendo rábanos en 400 reales.

- Otras dos de hueso hombre con una copa de vino en la mano y la otra un viejo y mujer que le está abrazando con marco de bronce, acero y adornos blancos en 400 reales.

- Otras dos de hueso de mujer y hombre bebiendo junto a un cubeto y dos hombres y una mujer con estuche en la mano y otra una mujer a caballo con saeta en la mano y otras figuras con marco de bronce, acero y adornos blancos en 400 reales.

- Otras dos de dos fábulas a buril sobre hueso de Anteo y Diana la primera con una orla alrededor de nácar con marco de bronce, acero y adornos blancos en 440 reales.

- Otras dos de hueso o lacadas con una mujer y un hombre dándole de beber y un ramo de flores en 150 reales.

- Otras dos de hueso de un hombre con un vaso en la mano mirándolo y una figura mirando una carátula con marco de bronce, acero y adornos blancos en 180 reales. 
- Otras dos de hombre con gallinas y un palo en la mano y otra con un hombre y un vaso de vino en la mano y una vieja con rueca con marco de bronce, acero y adornos blancos en 180 reales.

- Otras dos de hombre y mujer cantando y hombre con una copa de vino en la mano y una botella riyéndose en 200 reales.

- Otras dos de hueso con hombre haciendo bailar a su perro y hombre con una copa en la mano y una vieja con un papel escrito del tamaño de un real con marco de bronce, acero y adornos blancos en 180 reales.

- Otras tres de hueso con mujer hilando, niño con pájaro atado de un hilo y hombre con vaso de vino en la mano en 210 reales.

- Una vitela de casi cinco dedos con hombre mirando detrás de un relox en 240 reales.

- Una vitela de cuatro dedos con dos cupidos flechándose el uno al otro con marco de bronce, acero y adornos blancos en 90 reales.

- Una vitela en hueso por un lado mujer hilando en otro un hombre, un muchacho, un borrico en 90 reales.

- Una de hueso ambos lados con Pallas y Diana con una manzana de oro en la mano y Juno y fábula donde están metiendo un niño en el hueco de un árbol marco ovalado de acero en 240 reales.

- Una pintura sobre hueso ovalado con Marte y Venus engarce de acero y bronce colado en 150 reales.

- Una de hueso como figura de la Prudencia con marco de acero ovalado en 120 reales.

- Otra de hueso ambos lados una un viejo con redoma de vino en la mano, otro mujer vestida de azul con engarce acero colado y copete pabonado en 200 reales.

- Otra de viejo con copa de vino en la mano de un ochavo con engarce acero colado y copete pabonado en 90 reales.

- Otra sobre hueso dos hombres y una mujer con un vaso de vino en la mano con marco de acero colado ovalado en 120 reales.

- Una en vitela retrato de una santa con guirnaldas de flores marco de acero y hojas pabonadas en 120 reales.

- Una de mujer con cordero marco de acero y adorno pabonado en 180.

- Dos historia del Nacimiento y Adoración de los Reyes en marfil de relieve de casi una cuarta marco ébano y guarnición de plata en 1400 reales. 
La colección pictórica de D. Lorenzo Armengual de la Mota, peculiar ejemplo...

- Un medio relieve en marfil de calidad romano engarce de acero u bronce en 200.

- Otra del mismo tipo de dos mujeres dando de beber a un viejo en 250.

- Otra del mismo tipo de un baño con figuras de hombre y mujer en 300.

Esta relación se puede contrastar con la copia existente, en el Archivo Diocesano de Cádiz, del inventario realizado en su casa de Madrid, el 18 de Junio de 1715, antes de su toma de posesión como obispo de Cádiz ${ }^{31}$. Las obras fueron tasadas por Bernabé García ${ }^{32}$, maestro pintor en este arte, siendo esta misma tasación la que aparece en el inventario transcrito. Entre ambos inventarios las diferencias son mínimas, no encontrándose en el inventario gaditano las siguientes obras:

- Seis floreros de dos tercias de alto y media vara de ancho con marco negro y perfil dorado valorados en 132 reales.

- Una pintura de la Trinidad de la Tierra, de vara y media de alto por una vara de ancho, con marco negro, en 150 reales.

- Dos retratos de los reyes Phelipe $V$ y María Luisa de Saboya, de vara de alto y tres cuarta de ancho con marcos negros y dorados, valorados en 180 reales.

\footnotetext{
${ }^{31}$ El inventario se hizo por mandato del IIm. Sr. D. Juan Patricio, obispo de Selucia, tesorero general de Su Santidad y de la Cámara Apostólica y de los bienes, expolios y vacantes, ante el IImo. Sr. Patriarca de las Indias arzobispo de Trapezunda, con asistencia de D. Isidoro Porras, protonotario apostólico. En él indica, D. Lorenzo, que todos estos bienes habían sido adquiridos por donaciones y con los ingresos de sus anteriores cargos.

Este inventario nos muestra cómo, además de la importante colección pictórica contaba, el prelado, con algunas esculturas y joyas de interés, como: una efigie de Cristo Crucificado, en martil, clavado en una cruz de peral, valorado en 450 reales; una cruz de Caravaca con su vidrio y marco de peral, valorada en 15 reales; un agnus con su adorno, marco redondo guarnecido de plata, valorado en 50 reales; dos imágenes del Niño Jesús, uno con algunos atributos y el otro de resurrección, con una sierpe en los pies, en urnas de cedro y peral, valorados en 1000 reales; otro Niño Jesús de marfil en traje de Buen Pastor, puesto en un peñasco, con diferentes ovejas, unos ramos y una figura del Padre Eterno, todo de relieve, de marfil, valorado en 150 reales; una efigie de San Lorenzo con unas parrillas en la mano, valorado en 440; dos efigies de Santa Teresa, valoradas en 500 y 300 reales; un San Francisco en barro, con un Santo Cristo y una calavera en la mano, valorado en 800; una cruz de plata, valorada en 15 reales; y relieves en plata cincelada de Santo Tomás de Villanueva, San Francisco, en la escena de la impresión de las llagas, la Inmaculada, y San José, valorados en 840 reales, todos. A.D.CA. Legajo 3182, varios, papeles de la familia Armengual.

32 Fue éste un pintor de historia, nacido en Madrid en 1679, muerto en 1731, alumno de Juan Delgado, que trabajó para una iglesia de Alcalá de Henares. BENEZIT, E. Emmanuel. Dictiannaire critique et documentaire des peintres, sculpteurs, sgraveurs de tous les temps et de tous les pays, París, 1911, tomo IV, pág. 153.
} 
- Dos pinturas, la una con La Virgen, el Niño y San José; la otra de Santa Ana, la Virgen y San Joaquín, ambas pinturas en vidrio de casi tres cuartas de alto y media vara de ancho, con marcos negros y perfil dorado, en 900 reales.

- Otra imagen de Nuestra Señora de la Concepción, pintada en vidrio, de una vara de alto y tres cuartas de ancho con marcos negros y perfil dorado, valorada en 500 reales.

Componía, por tanto, esta colección un conjunto de 325 obras, valoradas en 56054 reales, de las cuales 65 eran miniaturas con marquitos de acero, que alcanzaban una valoración de 16590 reales. Este tipo de pintura muy raramente aparece citada en los inventarios hasta hoy conocidos, pero el hecho de que Palomino dedicara a ella los apartados IV y V, del capítulo IV de su tratado, nos indica que no era una práctica desconocida o totalmente desusada en este tiempo, más bien al contrario, ya que afirma, tras señalar que lo que expone en gran parte lo ha tomado de Pacheco, que no es su «intento hacer tratado especial de estas menudencias en adelante, sino de la pintura robusta, valiente, y manchada de las obras grandes, y espiritosas del temple, óleo, y fresco, por enriquecer el español, de lo que necesita, sin hacer empeño inútil de lo que abunda» 33.

Indica que «la iluminación, es, la que se hace reservando para el blanco, el que de su naturaleza tiene la superficie tersa de la vitela, papel, o hueso, donde se ejecuta" ${ }^{34}$, por lo cual se justifica que sean la vitela y el hueso los soportes fundamentales en el grupo de obras que consideramos.

Precisamente, la importante presencia y alto valor alcanzado por las miniaturas, algunas en relieve y la mayoría pintadas sobre vitela o hueso, es la característica más peculiar ${ }^{35}$ de esta colección. A pesar de que la tenencia de este tipo de obritas, sobre todo en los ámbitos cortesanos, no era excepcional, ya que en ellos, era frecuente el encargo de medallones cercados con pieles preciosas y esmaltes, pintados generalmente al óleo, sobre láminas de plata, tablitas de madera especialmente preparadas 0 , incluso, sobre naipes, utilizándose también para decorar, sobre vitela, las

33 Palomino, Antonio A. El museo pictórico y la escala óptica l. Theorica de la Pintura, Madrid, 1988, pág. 141.

34 Ibidem.

35 No parece ser ajena, esta característica, a una tendencia que, durante el siglo XVIIf, e incluso desde un poco antes, tiende a valorar lo gracioso y bonito como cualidad estética de moda, pareja al declive del gran arte, y por tanto de la gran pintura, que se asocia al triunfo del nuevo espíritu de salón. Minguet, Philipe. La estética del rococó, Madrid, 1992, págs. 212-213. 
ejecutorias de nobleza ${ }^{36}$, no puede considerarse habitual la posesión de tan significativa cantidad de obritas de este tipo. Frente a esta presencia de miniaturas, en la misma época es difícil encontrar un panorama semejante en otras colecciones. En los inventarios malagueños, por ejemplo, apenas se documenta la presencia de este tipo de obras ${ }^{37}$.

En el conjunto de la colección, llama la atención el predominio de las obras de tamaño mediano, pequeño y muy pequeño, mientras que aquéIlas que tienen formato grande o muy grande son únicamente veinte, lo que muestra, claramente, cómo la finalidad decorativa en los espacios domésticos impone, de manera forzosa, ese tipo de tamaños, incluso en las colecciones más importantes y entre aquéllos que pueden disponer de más amplias estancias en sus domicilios.

En su mayor parte, se trata de obras anónimas o de las que, al menos, no se especifica autor, correspondiendo las pocas firmadas o atribuidas, a pintores españoles relativamente recientes o de la segunda mitad del siglo anterior, excepción hecha de las obras de Alberto (posiblemente Durero) y El Bosco.

Junto a las anteriores las únicas obras extranjeras son las identificadas como flamencas y las de Durero, El Bosco, Pedro Cotto ${ }^{38}$ y el Caballero Farelli ${ }^{39}$, pudiendo serlo igualmente las copias de Rubens, Gerardo Segres ${ }^{40}$ y Palma. Los autores españoles presentes (Palomino,

36 PeREdA, Antonio. "Velázquez, pintor de miniaturas", Varia Velazqueña, Madrid, 1980, págs. 378-381.

${ }_{37}$ Las únicas excepciones, quizás, sean: las dos miniaturas que el canónigo Pedro de Ahumada manda a las madres María Teresa de San Agustín y María Teresa de Santa Inés en su testamento, otorgado el 23 de octubre de 1741 (A.H.P.MA. Escribanía de Juan Antonio de León y J. Díez de Medina, legajo 2796, año 1741, fols. 336-339); un retrato de la princesa de Vaudemont, relacionado entre los bienes de la Marquesa de! Riscalde, recibidos por su esposo, el Marqués de Riscalegre, gobernador de Málaga como consta en el recibo judicial de inventario, realizado el 10 de Noviembre de 1713 (A.H.P.MA. Escribanía de Pérez Padilla, legajo 2499, años 1712-1721, fols. 140-141.); y dos miniaturas de Nuestra Señora y San José, con molduras de ébano, guarnición de plata y cristal delante, que poseía en su oratorio D. Juan de la Torre Barrera, valorados en 996 reales (A.H.P.MA. Escribanía de Salvador de Salas, legajo 2574, año 1741-1742, fols. 102-108).

${ }^{38}$ En principio, la identificación de este pintor parece presentar cierta dificultad, pudiendo tratarse de Pedro de Cote, pintor que vive en Sevilla en el siglo XVI, hijo de Bartolomé de Cola. BENEZIT, E. Emmanuel. Op. cit., Tomo II, pág. 668.

${ }_{39}$ Posiblemente se trate de Giacomo Farelli, pintor de historia y retratos, nacido en Roma, en 1624 y muerto en Nápoles en 1706, a cuya escuela pertenece. Comenzó adoptando el estilo de Andrea Vaccaro, su primer maestro, para imitar, más tarde el estilo de Reni. Ibídem, tomo III, pág. 671.

40 Pintor de historias, natural de Anvers, que desarrolla su actividad en la primera mitad del siglo XVII. Hermano de Daniel Seghers, llegó a trabajar varios años en Madrid, para Felipe III. A su retorno a Anvers, y tras el fallecimiento de Rubens, fue uno de los pintores más ricos y célebres de su tiempo. Ibídem, tomo VII, pág. 697. 
Murillo, Cano, Arellano, Carreño) y los autores de los que poseía copias (Palma, Carraci, Rubens) parecen evidenciar una apertura del gusto artístico, de este prelado, hacia las formas coloristas y preferentemente clásicas, si bien la importantísima presencia de cuadros de género y paisajes, entre las que destacan las marinas, refleja un claro interés por lo flamenco y lo anecdótico.

La importancia y el volumen de esta colección queda, tras la relación expuesta, claramente evidenciada, pero la llegamos a comprender mejor si tenemos en cuenta que sólo existía en estos tiempos, en su ciudad natal, una colección de mayor volumen y tasación, la correspondiente al Conde de Buenavista D. José Guerrero y Chavarino, con 643 cuadros, valorados en 203022 reales ${ }^{41}$.

La colección estaba compuesta, en su mayoría, por obras de temática no religiosa $(69,2 \%)$. Las obras religiosas, sin embargo, a pesar de ser minoritarias $(29,8 \%)$, veían incrementado, significativamente, el porcentaje de participación en el valor total del conjunto. Alcanzaba un $40,1 \%$ del total, en que se tasaba la colección. Por tanto, a nivel general, se detecta, en este sentido, un mayor aprecio por las obras de este grupo, semejante al que se puede encontrar entre los miembros de la alta nobleza.

El conjunto de obras que tenía una presencia más significativa era el integrado por los cuadros de «diversos géneros profanos», que representaban un $63,4 \%$ de la colección, por contra llama la atención la escasa presencia de cuadros relacionados con la figura, vida y pasión de Cristo con un 2,7\%.

Las diferencias entre los porcentajes de número y valor de cuadros muestran leves incrementos en los valores monetarios de todos los conjuntos (comprendidos entre uno y cuatro puntos), excepción hecha del grupo de «diversos géneros profanos» en el que se aprecia un descenso de nueve puntos en el porcentaje correspondiente al valor, respecto al porcentaje de número de cuadros. De nuevo, esta composición, guarda una gran semejanza, con la distribución media que encontramos en las colecciones nobiliarias de la ciudad.

La importancia de la pintura integrada en el grupo «diversos géneros profanos» se hace patente, también, cuando observamos los subrupos temáticos con mayor presencia, ya que, de los siete más importantes, cuatro pertenecen a este grupo. Destacan, especialmente, los paisajes,

${ }^{41}$ Los autos de partición de sus bienes se cerraron el 21 de diciembre de 1741. A.H.P.MA. Escribanía de Hermenegildo Gil, legajo 2603, año 1741, fols. 854-926. 
de los cuales encontramos 119 obras (un $36,6 \%$ de toda la colección), y las escenas de género, representadas con 58 obras (un 17,8\%). En cuarta posición se sitúa fruteros y floreros, con 17 cuadros (un $5,2 \%$ ) y en séptima los retratos, con 11 ejemplares (un $3,4 \%$ ).

Las otras posiciones significativas corresponden a las imágenes de santos, que con 46 obras $(14,1 \%)$ se sitúan en tercera posición; de la Virgen sola o con el Niño, con 15 cuadros $(4,6 \%)$ en quinta; y mitológicas, que con 14 cuadros $(4,3 \%)$ aparecen en la sexta. Esta presencia de temas mitológicos, junto al segundo lugar ocupado por las escenas de género son, quizás, las notas más distintivas de esta colección, conferidoras de un aspecto más cortesano, acorde con la nueva línea que la reina intentó dar a las colecciones reales ${ }^{42}$.

El porcentaje sobre el valor total, que corresponde a cada uno de estos subgrupos no coincide exactamente con lo anteriormente expuesto. Si los paisajes mantienen en este concepto la misma posición, con un $30,7 \%$, las imágenes de santos ocupan el segundo lugar, con un $16,8 \%$, y las escenas de género el tercero, con un 15,8\%. Cómo éstas últimas, retratos y floreros o fruteros pierden importancia, en este aspecto, pasando a ocupar las posiciones octava y undécima, con porcentajes del $2,7 \%$ y $2 \%$.

Tienen, por contra, una presencia más significativa, por lo que a su valor se refiere, las imágenes de diferentes advocaciones de la virgen, situadas, con un $6,15 \%$, en quinto lugar; las escenas mitológicas, situadas en cuarto lugar, con un 6,2\%; las imágenes de la Virgen con Cristo y algún santo, situadas en sexto lugar, con un 3,9\%; los misterios de la vida de la Virgen, situados en séptima posición, con un 3,1\%; las escenas de la infancia de Cristo, situadas en novena posición, con un $2,3 \%$; y las escenas del Antiguo Testamento, situadas en décima, con un 2,2\%.

Los títulos concretos que más se repiten raramente alcanzan cifras significativas. Entre ellos se pueden destacar: treinta y ocho marinas, diez floreros, seis fruteros, cinco imágenes de la Virgen con el Niño, cinco escenas de la historia de José y cuatro de diferentes pasajes de la vida de San Pedro.

Si consideramos las obras que alcanzan mayor tasación observamos que, de los diecinueve cuadros con valor igual o superior a 500 reales, la

${ }_{42}$ Sobre esta cuestión ver BELdA NAVARRO, Carlos. "Valor y función de la pintura religiosa en los Reales Sitios: el Palacio Real y la Granja entre 1746-1774», El Arte en las Cortes Europeas (comunicaciones), Madrid, 1989, págs. 107-120. 
mayoría, trece, son de temática religiosa y el resto paisajes de diverso tipo, dos de ellos marinas, y uno de asunto mitológico. Entre los de temática religiosa casi la mitad, seis, son imágenes de santos o escenas de su vida, cuatro de temática mariana, ninguna pasional, y tres relacionados con la vida y misterios de Cristo, dos de la infancia y uno pasional.

El cuadro de mayor valor es uno de Alonso Cano, en el que se representa a La Virgen, san José, san Juan y un cordero, valorado en 1500 reales. Le sigue, curiosamente, una obrita que no es, exactamente una pintura, se trata de un altorrelieve en marfil, que representa El martirio de San Lorenzo, valorado en 1000 reales. En novecientos reales se valoran las tres obras siguientes. Entre ellas destaca la imagen de San Francisco, obra de El Greco, donada al Hospital de Mujeres de Cádiz, se trata de un lienzo grande, de vara y media de ancho por dos y media de alto, con marco tallado y dorado. Las otras dos son miniaturas, una de San José orlado de flores y otra de la Virgen con el Niño, la primera de ellas en vitela.

Entre este conjunto, de obras de mayor valor, destacan: un Descendimiento, en tabla, de pequeño tamaño, una cuarta, obra de Alberto, probablemente Durero, valorado en 700 reales; una Asunción, copia de Rubens, valorado en el mismo precio; una Marina grande, valorada en 700 reales, obra profana que alcanza mayor valor; una Adoración de los Reyes y un Nacimiento, ambos copias de Rubens, valoradas en 600 reales cada una; un Puerto de Nápoles, valorado en la misma cantidad, cifra que también se asigna a una miniatura en vitela, que representaba a Zeres y Juno.

Es de destacar, la importante presencia, especialmente entre su conjunto de miniaturas, de escenas que pueden calificarse "de taberna» o similares, con viejos, hombres bebiendo o fumando y mujeres, en las que la presencia de algunas figuras, como la mona sacando el dinero de la bolsa, la mujer con rueca, la mujer hilando, o el reloj, parecen encerrar significados de índole escatológica o moral, que se podían ver asociados a los valores estrictamente formales o pintorescos, para justificar su presencia en el patrimonio de un prelado.

El número de miniaturas que integraban esta colección hace de ella algo muy peculiar, al menos en función de los documentos que conocemos, ya que representaban el $20 \%$ de la colección y su valor alcanzaba un $30 \%$ de ella, lo que nos muestra la trascendencia que para el propietario tenían estas obritas.

En este conjunto, las obras aparecen realizadas, en su mayor parte, sobre hueso (40 de ellas, un $61,5 \%$, que participan en el valor total del conjunto con una cifra significativamente menor, un $43,3 \%$ ) y vitela, material en el que se realizan 19 obras $(29,2 \%$ del total). En él la temática de 
"géneros profanos" es claramente mayoritaria, influyendo de una manera determinante en la caracterización compositiva temática de toda la colección.

De las 65 obras, 41 forman parte del conjunto referido, correspondiendo 29 a escenas de género, a las que siguen, dentro del grupo, a gran distancia, los paisajes (siete). Frente al evidente predominio de este tipo de obras, sólo alcanzan cifras significativas las escenas mitológicas (nueve), mientras que son escasísimas las obras religiosas, trece. Cinco de ellas corresponden al Antiguo Testamento, cuatro son marianas, tres de santos y una de Cristo. Su valor muestra, sin embargo, un porcentaje mayor que el correspondiente a su cantidad: $29 \%$ frente a un $20 \%$.

La frecuencia de pintura no estrictamente religiosa no resulta extraña y puede comprobarse, como ha hecho Agüera Ros, en el caso de Murcia, para algunos prelados ${ }^{43}$ de esa ciudad. Lo que sí podría considerarse poco adecuado a su carácter clerical es la existencia, entre este patrimonio, de algunas obras de asunto mitológico, ya que, siguiendo las orientaciones del Concilio de Trento, las autoridades eclesiásticas, en diversas ocasiones (tercer Concilio Provincial de Milán del año 1573 o el Concilio de Malinas de 1570), decretan que en los jardines y casas de los eclesiásticos, si hubiese alguna pintura o estatua provocativa, o, en alguna manera, obscena o torpe, se retoque o se quite del todo, y en adelante no se pinte ni esculpa nada semejante ${ }^{44}$.

El disfrute de cargos en la corte, su propia formación, la lejanía de los duros tiempos de la reforma, y la creación de una mentalidad más claramente abierta hacia el goce de la belleza, pueden explicar la presencia de estas obras y el desentendimiento hacia estas directrices, que, por otro lado, no parece que se observaran con rigor, como muestra la reiterativa repetición de estos mandatos (Concilio mechilense de 1607).

43 Don Juan Bravo Asprilla, en 1663, contaba con 52 obras de las que sólo ocho eran religiosas, prefiriendo la pintura de género y aquella que perpetuaba la monarquía, y $D$. Juan de Valdivieso, contaba con una colección de 61 cuadros en la que se encontraban muy compensados los temas sacros y profanos. AgüERA Ros, José Carlos. Pintura y sociedad en el siglo XVII. Murcia, un centro del barroco español, Murcia, 1994, págs. 360-363.

${ }^{44}$ HoRnedo, Rafael $\mathrm{M}^{a}$ de «El arte en Trento», Razón y $\mathrm{Fe}$, tomo 131, enero-abril, Madrid, 1945, págs. 203-232. 
